\title{
複数構造体の連成運動を考慮した フラップゲートの段波応答に関する数值解析 \\ NUMERICAL ANALYSIS FOR RESPONSE OF FLAP-GATE AGAINST BORE-TYPE TSUNAMIS CONSIDERING INTERACTION OF MULTIPALE STRUCTURES' MOTIONS
}

\author{
木村雄一郎 1 ・柳 浩敏 2 ・森西晃嗣 3 ・森 信人 4 ・間瀬 肇 4 \\ Yuichiro KIMURA, Hirotoshi YANAGI, Koji MORINISHI, \\ Nobuhito MORI and Hajime MASE \\ 1正会員 工修 日立造船株式会社 技術研究所 (广551-0022 大阪市大正区船町2-2-11) \\ 2 日立造船株式会社 技術研究所（广551-0022 大阪市大正区船町2-2-11) \\ 3 工博 京都工芸繊維大学 機械システム工学科（† 606-8585 京都市左京区松ヶ崎御所海道町) \\ 4正会員 工博 京都大学防㷋研究所 沿岸災害研究分野 (下611-0011 京都府宇治市五ヶ庄)
}

\begin{abstract}
A flap-gate breakwater is a new type structure for coastal disaster reduction against tsunamis and storm surges. The flap-gate usually lies down on the bottom of sea and rises up as a seawall with its buoyancy when tsunamis or storm surges occur. In past studies, capabilities of the flap-gate against tsunamis have been confirmed by hydraulic model experiences, and the characteristics of the gate motion against waves and sinetype tsunamis have been clarified by numerical simulations considering fluid-structure interaction. The present study improves the numerical simulation model so as to consider momentary flap-gate motions against boretype tsunamis and interaction between the gate and a fluid resistance plate controlling rapid motions of the gate. As a result, good agreement is obtained between numerical simulations and model experiments.
\end{abstract}

Key Words : flap-gate, tsunami, numerical analysis, over grid method, level set method, multiple structures' interaction

\section{1.はじめに}

南海，東南海および東海地震津波に代表される 大規模地震津波の発生リスクの高まりを背景に, 著 者らは，フラップゲート式可動防波堤（以下，フ ラップゲートと呼称）の開発を進めている。フラッ プゲートは，図-1に示すように，扉体，函体および テンションロッドを主要な部材として構成される可 動式の防災施設である. 屝体は, 所定の幅で分割さ れ, 一端を回転支承として函体に連結し, 他端に与 えた浮力を利用して水面まで浮上し港口を閉鎖する. 浮力によって水面まで浮上した扉体は，津波あるい は高潮によって生じる港外水位上昇により，所定の 高さまで起立し連続した止水壁をなす。テンション ロッドは，上部テンションロッドおよび下部テン ションロッドの $2 つ の$ 部材からなり, 起立した扉体 に作用する水圧荷重を支持するとともに，対をなす 下部テンションロッド間に設置した流体抵抗板が，
扉体の急激な起立動作を抑制する.

フラップゲートは, 従来の津波・高潮防災施設 とは異なり, 通常海底に倒伏しているため, 海水の 交換を妨げず景観への影響も小さい。また，フラッ プゲートの扉体は，海底に設置された水平軸を回転 中心として起伏するため, 港口の径間に対する制限 がない，さらに，フラップゲートは，従来の防災施 設と比較して，建設費用ならびに維持管理費用の大 幅な削減が可能であり，多くの利点を有している。

これまで, 実験的な研究 ${ }^{1,2)}$ によってフラップ ゲートの防災施設としての有用性が検証されるとと もに, 解析的な研究 ${ }^{3), 4}$ を通してフラップゲートの 流体特性の多くが明らかにされてきた。前述のよう に，フラップゲートは，抵抗板の流体抵抗を利用す ることにより，屝体の起立速度を抑制し，段波性の 津波などによる衝撃波圧を低減する機能を有してい る。しかしながら，この流体特性は，模型実験によ り確認されてはいるものの，これまで解析的な検証 
はなされておらず，そのメカニズムの詳細について は未解明な部分もあった。

そこで, 本研究では, (1)段波津波を対象とした 衝撃的な波圧の評価，ならびに，(2)扉体および抵抗 板の $2 つ の$ 構造体の連成運動を考慮した流体特性の 検証を行うことを目的として, 数值解析モデルの高 度化を行った。連成解析モデルの構築には, 重合格 子法 ${ }^{5}$ およびレベルセット法 ${ }^{6}$ を使用し, 解析モデ ルの精度検証には従来の水理模型実験の結果を使用 した. 以下, 模型実験, 数值解析モデル, 解析結果 の考察について記す.

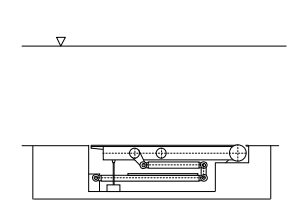

(a) 倒伏状態 (通常時)

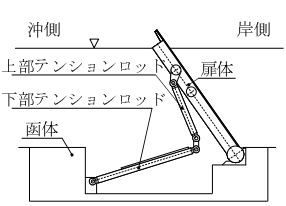

(b) 浮上状態 （港口閉鎖時）

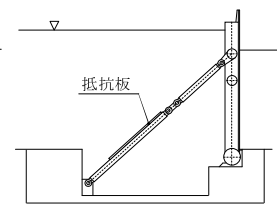

(c) 起立状態 （津波発生時）
図-1 フラップゲート式可動防波堤の側面図

\section{2. 水理模型実験}

水理模型実験は，ピストン式造波装置を備えた長 さ $50 \mathrm{~m}$, 幅 $1 \mathrm{~m}$ の2次元造波水槽を用い, 縮尺 $1 / 30^{2)}$ および $1 / 48^{1)}$ の 2 種類の実験模型を使用して実施した。 実験では，造波板のストロークおよび動作時間を変 化させることで数通りの孤立波を造波し，水槽内に 構築した傾斜面上でそれらの孤立波を研波させるこ とにより，模擬的な段波性津波を作成した，双方の 模型実験における実験装置全体の概略を図-2に示す. 実験では，抵抗板を設置していないフラップゲート， 抵抗板を設置したフラップゲートに加え，扉体を90 度に固定した鉛直壁についても実験の対象とした。 実験模型は, 水深 $13 \mathrm{~m}$ の実海域を対象とした実機を 模型化したものであり，実機の扉体一門の高さは22 $\mathrm{m}$, 対応する $1 / 30$ 縮尺模型の扉体高さは $72 \mathrm{~cm}, 1 / 48$ 縮尺模型の扉体高さは46 cm に相当する．1/30縮尺 模型実験に使用したフラップゲートの写真を写真-1 に示寸.

段波性の津波は，引波によって水位が低下した際 に生じるものとし, 各実験における水深は，1/30縮 尺実験では $22.8 \mathrm{~cm}$ (実機換算水深 : $7 \mathrm{~m}$ )，1/48縮 尺模型実験では $10 \mathrm{~cm}$ よび $20 \mathrm{~cm}$ （実機換算水深 :

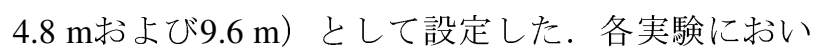
て作成された，段波性津波の最大振幅および段波波 高の一例を表-1に示す。

\section{3. 数值解析モデル}

\section{（1）重合格子法}

重合格子法とは，図-3のように主格子中に補助 格子を重放て配置することで数值解析を行う手法で

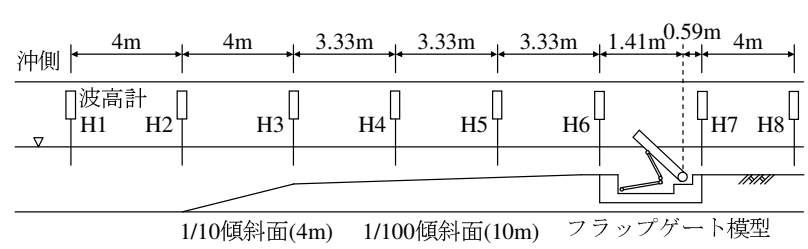

(a) 1/30縮尺模型実験

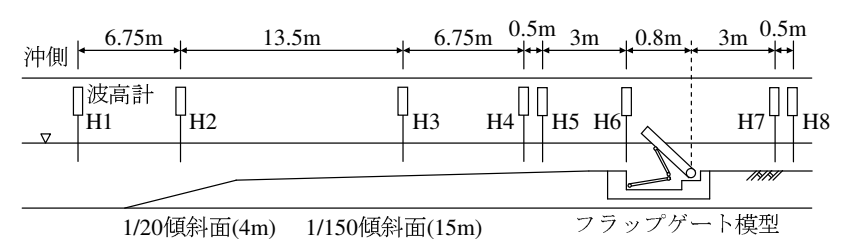

(b) $1 / 48$ 縮尺模型実験

図-2 実験装置の概略図

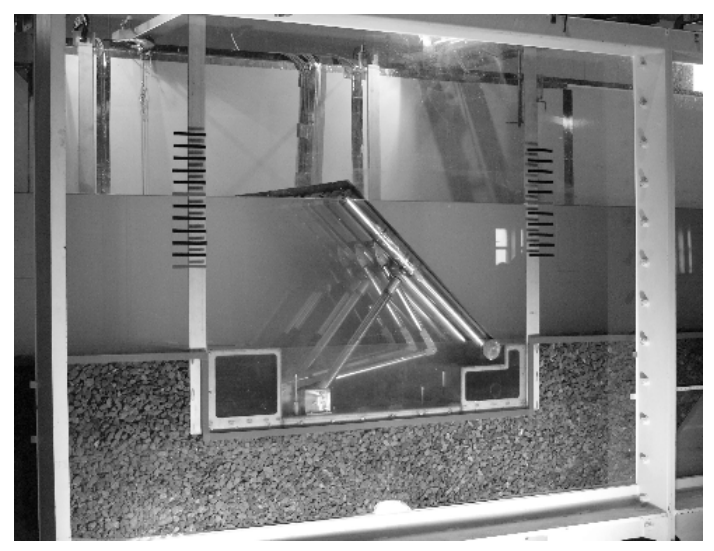

写真-1 フラップゲート実験模型（左 : 沖側）

表-1 実験で使用した段波の最大振幅と段波波高

\begin{tabular}{c|c|c|c}
\hline \multirow{2}{*}{ 模型縮尺 } & $\begin{array}{c}\text { 水深 } \\
h[\mathrm{~cm}]\end{array}$ & $\begin{array}{c}\text { 最大振幅 } \\
H_{\max }[\mathrm{cm}]\end{array}$ & $\begin{array}{c}\text { 段波波高 } \\
\zeta[\mathrm{cm}]\end{array}$ \\
\hline \multirow{3}{*}{$1 / 30$} & \multirow{2}{*}{22.8} & 24.8 & 9.7 \\
\cline { 3 - 4 } & \multirow{3}{*}{$1 / 48$} & 22.6 & 12.1 \\
\hline \multirow{3}{*}{10} & 6.9 & 4.4 \\
\cline { 3 - 4 } & & 7.3 & 5.3 \\
\cline { 3 - 4 } & & 8.6 & 6.1 \\
\cline { 3 - 4 } & \multirow{3}{*}{20} & 9.9 & 6.8 \\
\cline { 3 - 4 } & & 16.1 & 4.7 \\
\cline { 3 - 4 } & & 13.7 & 5.9 \\
\cline { 3 - 4 } & & 12.9 & 7.1 \\
\hline
\end{tabular}

ある，主格子では，構造物と重なる格子点およびそ の近傍の格子点は非計算格子' $\boldsymbol{~ ' ~ ( 以 下 , ~ H O L E ~ と ~}$ 呼称）として扱われ，その他の格子上において物理 量の計算が行われる。補助格子における最外周部の 境界“○’には主格子から物理量が内挿され, 補助格 子領域における計算が行われた後，主格子における HOLE 点周囲の格子‘ $\square$ ’に物理量が戻される。

HOLE は, 物体から数周目の補助格子における周方 向（物体に沿う方向）の曲線を HOLE 境界とした ときに，その内部に含まれる主格子点をさす．内挿 には, 以下に示寸二次元の線形内挿を用いる.

$\left[\begin{array}{l}x_{P} \\ y_{P} \\ q_{P}\end{array}\right]=(1-X)(1-Y)\left[\begin{array}{l}x_{A} \\ y_{A} \\ q_{A}\end{array}\right]+X(1-Y)\left[\begin{array}{l}x_{B} \\ y_{B} \\ q_{B}\end{array}\right]+X Y\left[\begin{array}{l}x_{C} \\ y_{C} \\ q_{C}\end{array}\right]+(1-X) Y\left[\begin{array}{l}x_{D} \\ y_{D} \\ q_{D}\end{array}\right]$ 
ここで, 添え字 $A, B, C$ および $D$ は主格子点 $\mathrm{P}$ を 内包寸る補助格子上のセルの各頂点を表し（図-3左 下の拡大図参照）， $x, y$ は座標， $q$ は物理量をそれ ぞれ表す。式(1)の上2式を用いて $X, Y$ を求め，そ れらを3つ目の式に代入することで，主格子点 $\mathrm{P}$ に内挿される物理量 $q_{P}$ が求められる. 補助格子の 最外周の境界についても同様の方法により算定され， 主格子から補助格子一物理量が内挿される.

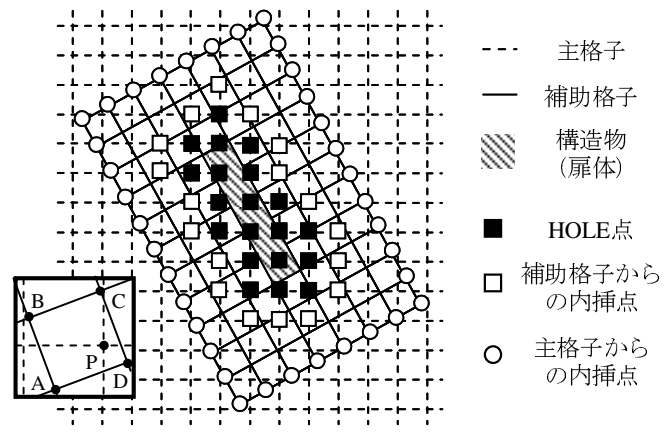

図-3 重合格子法の概念図

\section{（2）レベルセット法}

レベルセット法は, 異なる相の相界面を追跡寸 ることを目的とする界面捕捉法の1つであり，相界 面より液相側が正，気相側が負となるような垂直距 離関数（レベルセット関数）を用いて相界面を捕捉 する. レベルセット関数 $f$ は相界面に有限な厚さ $\alpha$ を持たせることができ, 密度や粘性係数のように相 界面で急激に変化するものでも，その界面の厚さに 応じて值を分布させ，比較的安定した計算を行うこ とができる，密度および粘性係数は，以下の式を用 いて各計算セルに付与される.

$$
\begin{gathered}
\rho= \begin{cases}\rho_{w} & f \geq \alpha \\
\rho_{a} & f \leq-\alpha \\
\tilde{\rho}+\Delta \rho \sin (\pi f / 2 \alpha) & \text { otherwise }\end{cases} \\
\mu= \begin{cases}\mu_{w} & f \geq \alpha \\
\mu_{a} & f \leq-\alpha \\
\tilde{\mu}+\Delta \mu \sin (\pi f / 2 \alpha) & \text { otherwise }\end{cases}
\end{gathered}
$$

ここで， $\rho_{w}, \rho_{a}$ は液相と気相の密度， $\mu_{w}, \mu_{a}$ は液 相と気相の粘性係数, 〜 (チルダ) は両者の平均值, பは両者の差の $1 / 2$ をそれぞれ示す.

\section{（3）数値計算法}

本研究では，非圧縮性流体を対象としている。ま た，非圧縮性流体の計算手法として擬似圧縮性法を 使用するため, 非圧縮性ナビエ・ストークス方程式 に擬似時間微分項を加えた擬似圧縮性ナビエ・ス トークス方程式を支配方程式として使用寸る（式 (3a) (3c)参照) . 擬似時間に対寸る定常解が得ら れたとき擬似時間微分項は 0 となり，この方程式は 非圧縮性ナビエ・ストークス方程式と等しくなる.

$$
\begin{gathered}
\frac{\partial p}{\partial \tau}+\frac{\partial u}{\partial x}+\frac{\partial v}{\partial y}=0 \\
\frac{\partial u}{\partial \tau}+\frac{\partial u}{\partial t}+u \frac{\partial u}{\partial x}+v \frac{\partial u}{\partial y}+\frac{\partial p}{\partial x}=\frac{1}{R e}\left[\frac{\partial^{2} u}{\partial x^{2}}+\frac{\partial^{2} u}{\partial y^{2}}\right]+f_{x} \\
\frac{\partial v}{\partial \tau}+\frac{\partial v}{\partial t}+u \frac{\partial v}{\partial x}+v \frac{\partial v}{\partial y}+\frac{\partial p}{\partial y}=\frac{1}{\operatorname{Re}}\left[\frac{\partial^{2} v}{\partial x^{2}}+\frac{\partial^{2} v}{\partial y^{2}}\right]+f_{y}
\end{gathered}
$$

ここで, $p$ は圧力, $u$ は $x$ 方向の流速, $v$ は $y$ 方向 の流速， $t$ は実時間， $\tau$ は擬似時間，Re はレイノル ズ数, $f_{x}$ は $x$ 方向に生じる外力, $f_{y}$ は $y$ 方向に生じ る外力をそれぞれ表すものである。

空間微分項の離散化は，2次精度風上差分を用い て行った。また，実時間に対する積分には，2次精 度の後退差分法を使用した。

重合格子法，レベルセット法および数值計算法の 詳細ついては，著者らの論文 ${ }^{5), 6}$ を参考にされたい。

\section{（4）複数構造体の連成}

抵抗板は，扉体本体と同様，補助格子を用いて作 成した，モデル化を簡易にするため，抵抗板の比重 は1とし，計算の安定性を高めるために，抵抗板の 厚さは実験模型よりもやや厚く設定した.

抵抗板のモデル化は, 次に示すようなアルゴリズ ムを追加することで行った。まず，下部テンション ロッドの設置位置に，テンションロッドと函体との 係留点を中心として回転できる2つ目の補助格子を 配置し，その補助格子を用いて実験の条件と合うよ うに抵抗板を形成した。抵抗板に作用するモーメン 卜は，抵抗板表面に作用寸る流体力に回転軸からの 距離を乗じ，それを抵抗板の全周にわたって積分す ることで算出される，次に，前記モーメントを上部 テンションロッドと扉体本体との接合点に作用する 荷重として換算した上で，扉体本体に直接作用する 流体力と合わせ，扉体に作用寸る外力として運動方 程式に追加する. 流体力によって抵抗板に直接作用 するモーメント $M_{F}$ は, 以下の式により, 屝体と上 部テンションロッドとの接合点に作用寸るモーメン 卜 $M_{P}$ として換算される.

$$
M_{P}=\frac{l_{2}}{l_{1}} \cdot \frac{\sin \theta_{2}}{\sin \theta_{1}} M_{F}
$$

ここで， $\theta_{1}$ は下部テンションロッドと上部テン ションロッドのなす角, $\theta_{2}$ は上部テンションロッ ドと扉体のな寸角, $l_{1}$ は下部テンションロッドの長 さ， $l_{2}$ は扉体回転軸からロッドとの接合点までの長 さを示す。

運動方程式から得られた扉体変位量をもとに抵抗 板の変位量を幾何学的に算出し, 補助格子とともに 抵抗板を回転変位させる。これらのフローを所定の 収束条件が満たされるまで内部反復計算することで, 
扉体と抵抗板の連成運動を考慮した適正な変位量が 算出される.

主格子および扉体と抵抗板とを構成する補助格子 の模式図を図-4に示す。図-4は，実機換算值で水深 を13 mとした際の, 水面まで浮上した屝体と抵抗板 との位置関係を示すものである。図-4では，双方の 補助格子が重なっている. 補助格子上の最外周の格 子点は, 主格子から物理量が内挿されるため, 補助 格子同士の重なりは, 数值計算上, 問題とはならな い.ただし, 補助格子の内挿点が主格子上の HOLE 点と重なった場合, HOLE 点上では数值計算が行わ れないため, 物理量を得ることができない.よって, 図-5のように，構造体と重なる補助格子を新たな HOLE 点として設定し, 物理量は, さらにその周囲 の格子点から内挿されるよう改良した。しかし, 補 助格子で構成される構造体同士が極端に接近した場 合，物理量を得るための内挿点がなくなる．格子サ イズを小さくすることで，このような問題を回避す ることも可能ではあるが，ここでは，構造体同士が 接近しすぎない条件, つまり，水位が比較的高い条 件の下で数值解析を実施することとした。

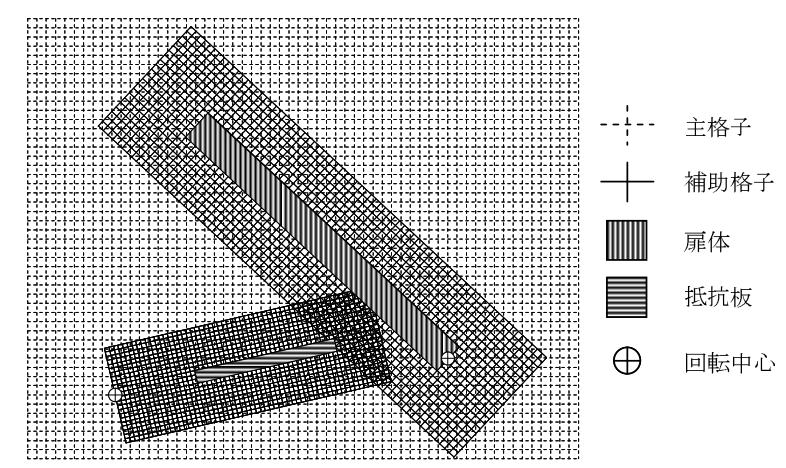

図-4 主格子と補助格子の位置関係

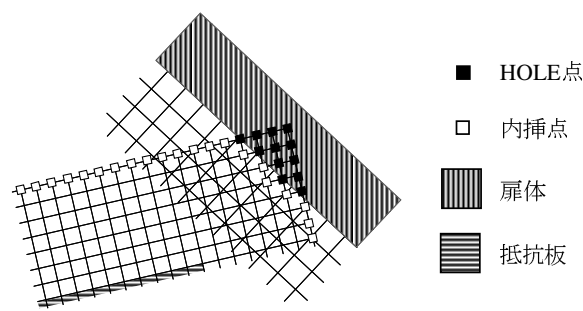

図-5 補助格子同士が接近した場合の取り扱い

\section{（5）解析条件}

数值解析は， $27.6 \mathrm{~m}$ の2次元数值波動水路上に， $1 / 30$ 縮尺のフラップゲートの扉体部，あるいは扉体 と抵抗板の双方を模擬する補助格子を配置して行っ た。主格子における格子数は，水平方向440グリッ ド，鉛直方向 65 グリッドとし，フラップゲート設置 位置の周囲については計算格子を密に配置した。主 格子における最小の格子間隔は $20 \mathrm{~mm} ゙$ あ。また， 屝体を表す補助格子は，屝体の長手方向74グリッド, 扉体の厚さ方向29グリッドとして作成し, 扉体部分
を60グリッド×5グリッドの格子により形成した。 また，抵抗板を表す補助格子については，長手方向 57 リッド，厚さ方向23グリッドとして作成し，29 グリッド×3グリッドの格子により抵抗板を形成し た。扉体および抵抗板を形成する補助格子の格子間

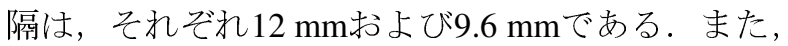
屝体を90度で固定した鉛直壁についても，数值計算 の対象とした。

数值解析では，段波波高の調整を容易にするため， 水柱崩壊により段波性津波を作成した。水柱の作成 には，数值波動水路の沖側を不透過境界，岸側を透 過境界とした上で，フラップゲートの沖側に所定の 長さおよび高さの水塊を配置し，計算開始とともに それらを崩壊させた。解析における水深の条件，設 定した水柱の容積ならびに発生した段波の諸量を 表-2に示す。ただし，前述のように，抵抗板を導入 した解析モデルでは補助格子同士の接近を防ぐため, 水深が比較的高い条件, 具体的には水深 $42.4 \mathrm{~cm}$ お よび $48.9 \mathrm{~cm} の$ 条件のみを対象とした。

表-2 段波の作成条件と発生した段波の諸量

\begin{tabular}{|c|c|c|c|c|c|c|c|}
\hline \multicolumn{3}{|c|}{ 実機 } & \multicolumn{4}{|c|}{ 数值解析（1/30縮尺） } & \multirow{3}{*}{$\zeta / h$} \\
\hline 水深 & 段波波高 & 最大振幅 & 水深 & 水柱容積 & 段波波高 & 最大振幅 & \\
\hline$h[\mathrm{~m}]$ & $\zeta[\mathrm{m}]$ & $H_{\max }[\mathrm{m}]$ & $h[\mathrm{~m}]$ & $V\left[\mathrm{~m}^{3} / \mathrm{m}\right]$ & $\zeta[\mathrm{cm}]$ & $H_{\max }[\mathrm{cm}]$ & \\
\hline \multirow{8}{*}{5} & 1.39 & 1.83 & \multirow{8}{*}{16.3} & 0.587 & 4.5 & 6.0 & 0.278 \\
\hline & 1.82 & 2.40 & & 0.782 & 5.9 & 7.8 & 0.364 \\
\hline & 2.22 & 2.98 & & 0.978 & 7.2 & 9.7 & 0.443 \\
\hline & 2.65 & 3.45 & & 1.174 & 8.7 & 11.2 & 0.531 \\
\hline & 3.05 & 3.52 & & 1.369 & 9.9 & 11.5 & 0.609 \\
\hline & 3.56 & 3.58 & & 1.565 & 11.6 & 11.7 & 0.711 \\
\hline & 3.92 & 4.00 & & 1.760 & 12.8 & 13.0 & 0.783 \\
\hline & 4.25 & 4.35 & & 1.956 & 13.9 & 14.2 & 0.850 \\
\hline \multirow{8}{*}{7} & 1.27 & 1.79 & \multirow{8}{*}{22.8} & 0.438 & 4.1 & 5.8 & 0.181 \\
\hline & 1.88 & 2.73 & & 0.657 & 6.1 & 8.9 & 0.269 \\
\hline & 2.44 & 3.68 & & 0.876 & 8.0 & 12.0 & 0.349 \\
\hline & 3.08 & 4.40 & & 1.095 & 10.0 & 14.3 & 0.440 \\
\hline & 3.71 & 4.14 & & 1.314 & 12.1 & 13.5 & 0.530 \\
\hline & 4.24 & 4.69 & & 1.533 & 13.8 & 15.3 & 0.606 \\
\hline & 4.84 & 5.09 & & 1.753 & 15.8 & 16.6 & 0.692 \\
\hline & 5.42 & 5.56 & & 1.972 & 17.7 & 18.1 & 0.774 \\
\hline \multirow{8}{*}{9} & 0.86 & 1.15 & \multirow{8}{*}{29.3} & 0.211 & 2.8 & 3.7 & 0.096 \\
\hline & 1.63 & 2.37 & & 0.422 & 5.3 & 7.7 & 0.181 \\
\hline & 2.38 & 3.68 & & 0.634 & 7.7 & 12.0 & 0.264 \\
\hline & 3.14 & 5.01 & & 0.845 & 10.2 & 16.3 & 0.348 \\
\hline & 4.01 & 4.70 & & 1.056 & 13.1 & 15.3 & 0.445 \\
\hline & 4.73 & 5.29 & & 1.267 & 15.4 & 17.2 & 0.526 \\
\hline & 5.51 & 5.93 & & 1.479 & 18.0 & 19.3 & 0.613 \\
\hline & 6.27 & 6.60 & & 1.690 & 20.4 & 21.5 & 0.697 \\
\hline \multirow{8}{*}{11} & 0.79 & 1.04 & \multirow{8}{*}{35.9} & 0.161 & 2.6 & 3.4 & 0.071 \\
\hline & 1.49 & 2.16 & & 0.323 & 4.9 & 7.0 & 0.136 \\
\hline & 2.17 & 3.33 & & 0.484 & 7.1 & 10.8 & 0.197 \\
\hline & 2.91 & 4.58 & & 0.645 & 9.5 & 14.9 & 0.264 \\
\hline & 3.56 & 5.85 & & 0.807 & 11.6 & 19.1 & 0.324 \\
\hline & 4.39 & 6.13 & & 0.968 & 14.3 & 20.0 & 0.399 \\
\hline & 5.11 & 6.17 & & 1.130 & 16.7 & 20.1 & 0.465 \\
\hline & 5.85 & 7.10 & & 1.291 & 19.1 & 23.1 & 0.532 \\
\hline \multirow{8}{*}{13} & 0.54 & 0.74 & \multirow{8}{*}{42.4} & 0.102 & 1.8 & 2.4 & 0.042 \\
\hline & 1.28 & 1.73 & & 0.203 & 4.2 & 5.7 & 0.099 \\
\hline & 1.83 & 2.64 & & 0.305 & 6.0 & 8.6 & 0.141 \\
\hline & 2.39 & 3.58 & & 0.407 & 7.8 & 11.7 & 0.184 \\
\hline & 2.94 & 4.54 & & 0.509 & 9.6 & 14.8 & 0.226 \\
\hline & 3.49 & 5.57 & & 0.610 & 11.4 & 18.1 & 0.268 \\
\hline & 3.99 & 6.54 & & 0.712 & 13.0 & 21.3 & 0.307 \\
\hline & 4.52 & 7.54 & & 0.814 & 14.7 & 24.6 & 0.348 \\
\hline \multirow{8}{*}{15} & 0.71 & 1.00 & \multirow{8}{*}{48.9} & 0.088 & 2.3 & 3.3 & 0.048 \\
\hline & 1.28 & 2.04 & & 0.176 & 4.2 & 6.6 & 0.085 \\
\hline & 2.01 & 3.06 & & 0.264 & 6.5 & 10.0 & 0.134 \\
\hline & 2.61 & 4.17 & & 0.352 & 8.5 & 13.6 & 0.174 \\
\hline & 3.27 & 5.33 & & 0.440 & 10.7 & 17.4 & 0.218 \\
\hline & 3.82 & 6.52 & & 0.528 & 12.5 & 21.3 & 0.255 \\
\hline & 4.45 & 7.71 & & 0.616 & 14.5 & 25.1 & 0.297 \\
\hline & 5.08 & 9.00 & & 0.704 & 16.5 & 29.3 & 0.338 \\
\hline
\end{tabular}




\section{4. 解析結果に対する考察}

（1）港内外水位と扉体角度の時間変化

水深 $h=42.4 \mathrm{~cm}$ の条件において，抵抗板を導入し ないフラップゲートに段波津波を作用させた際の港 外水位, 港内水位および扉体角度の時間変化を図-7, 図-8および図-9に示す，図-7および図-8より，段波 波高が高いケースほど，扉体の起立によって港内に 生じる発生波が大きいことがわかる。しかしながら， フラップゲートは到来する段波の大部分を遮蔽して おり, 十分な防災効果が確認できる. また, 抵抗板 を導入したケースであっても，港内に生じる発生波 の波高に顕著な差はみられなかった。 これらの傾向 は，実験結果とも概致一致するものであった。
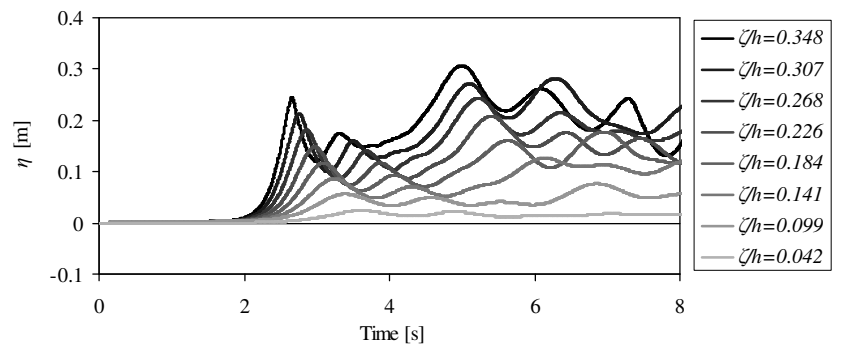

図-7 港外水位の時間変化の一例

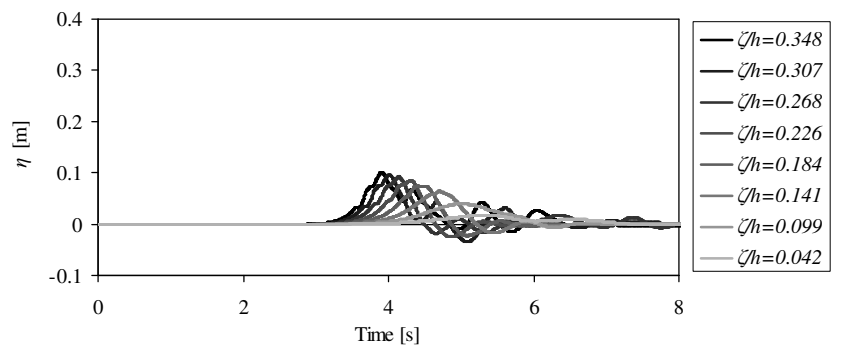

図-8 港内水位の時間変化の一例

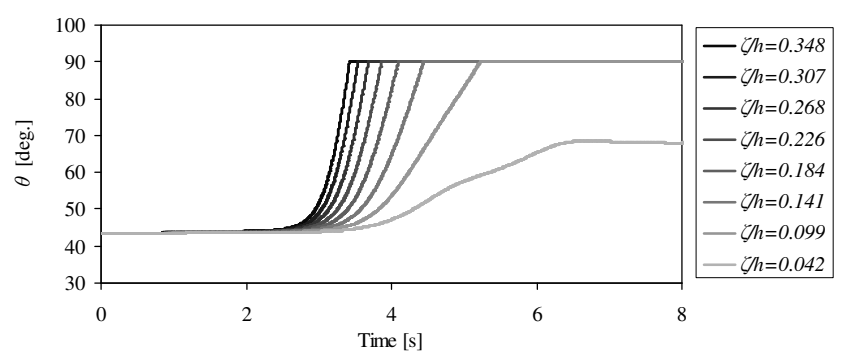

図-9 扉体角度の時間変化の一例

\section{（2）抵抗板に作用する流体力}

$h=42.4 \mathrm{~cm}, \zeta / h=0.141$ の条件の下での解析結果に ついて，抵抗板に直接作用する流体力，および段波 流速と抵抗板の相対速度より算出した抗力の時間変 化を図-10に示す。ここで算出した抗力は，抵抗板 に作用する流体力の大きさの目安となるものである. 図-10より，抵抗板に作用寸る流体力は，扉体角度 が86度以下の領域では, 相対流速より推測される抗 力と比較して小さく, その後, 双方の大小が逆転し ている，そこで，テンションロッドを介して扉体に
作用するモーメントを，上部テンションロッドと下 部テンションロッドのなす角度の関数を用いて, 式 (5)のように補正を行った.

$$
M_{P}^{\prime}=M_{P} \cdot \sin ^{-1} \theta_{1}
$$

$M_{P}{ }^{\prime}$ は，テンションロッドが扉体に及ぼす補正後の モーメントを示す，補正前および補正後における， テンションロッドに生じる軸力の時間変化を図-11 に示寸，補正により，軸力のピーク值がカットされ， その立ち上がりの傾きが緩和されているのが確認で きる。また，図-10に示した流体力は，振動しなが ら増加する様子がみられるが，これは，抵抗板の裏 面に生じた微小な擾乱によるものである.

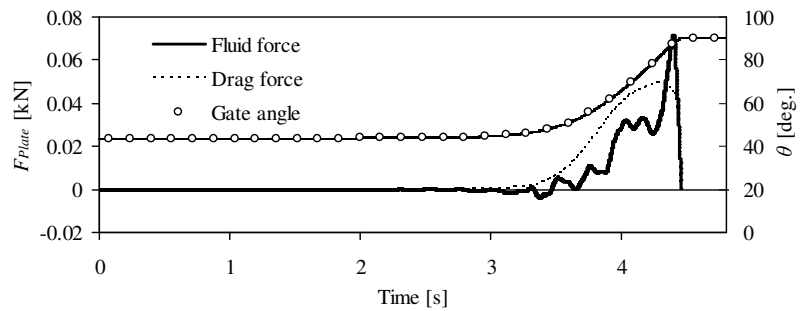

図-10 抵抗板が扉体に及ぼす作用力の時間変化

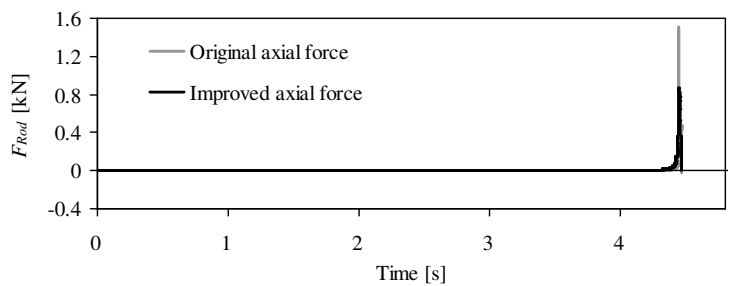

図-11 補正前および補正後のテンションロッド軸力

\section{（3）段波波圧の鉛直分布}

$h=42.4 \mathrm{~cm}$ での解析結果について，抵抗板を導入 しないフラップゲートおよび抵抗板を導入したフ ラップゲートの，扉体に作用する最大波圧の鉛直分 布を図-12に示す．図-12より，抵抗板を導入するこ とにより，扉体に作用寸る波圧が $1 / 2 \sim 1 / 3$ に軽減で きていることがわかる。この軽減率は, 模型実験に よる結果と概ね一致するものであった.

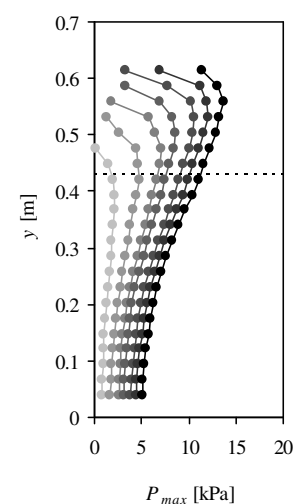

(a) 抵抗板なし

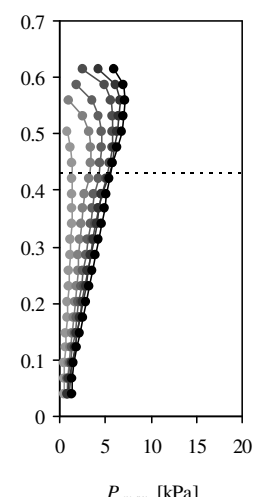

(b) 抵抗板あり
図-12 扉体に作用寸る最大波圧の鉛直分布の比較 


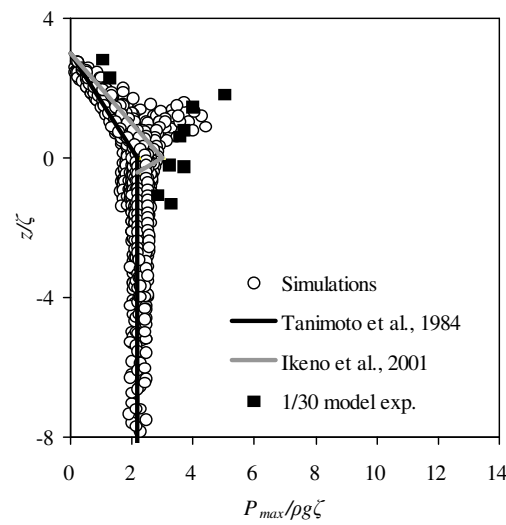

(a) 鉛直壁

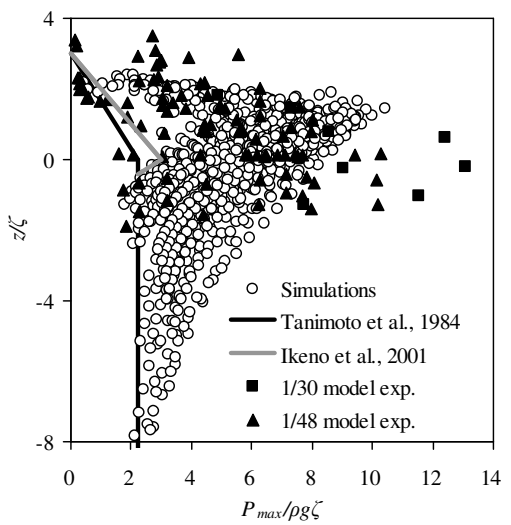

(b) 抵抗板なしフラップゲート

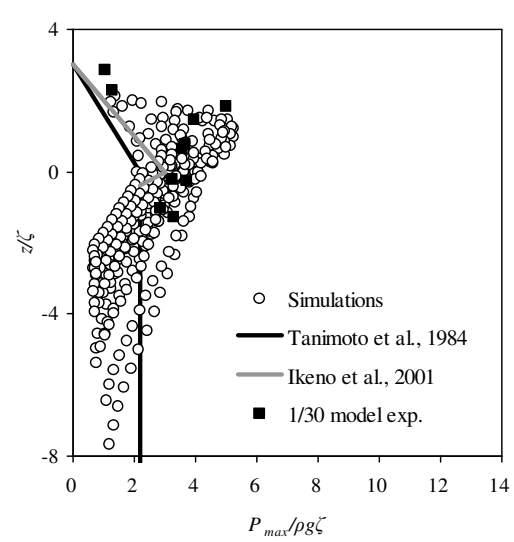

(c) 抵抗板つきフラップゲート

図-13 無次元化した最大波圧の鉛直分布

図-13に，鉛直壁，抵抗板を導入しないフラップ ゲートあるいは抵抗板を導入したフラップゲートに 段波津波を作用させた際の，無次元化した最大波圧 の鉛直分布を示す。図中, 横軸は比重量 $\rho g$ および 段波波高 $\zeta$ で無次元化した波圧，縦軸は段波波高 $\zeta$ で無次元化した水面からの高さを示寸ものである. また, 各図には, 水理模型実験の結果に加え, 谷本 ら あるいは池野ら $^{8)}$ が提案する実験式も追加した。

図-13(a)より, 鉛直壁に作用寸る波圧の解析結果 は, 従来の実験式上にほぼ分布しており, 静水面 $(z / \zeta=0)$ よりやや上方で大きくなる波圧について も, 水理模型実験の結果とよく一致した。抵抗板を 導入しないフラップゲートに生じる段波波圧は，実 験結果および解析結果ともに図中の広い範囲に分布 しているが，解析結果は，実験結果の範囲を概ね包 括しているといえる. 図-13(c)より，抵抗板を導入 したことで，扉体に作用する波圧は，鉛直壁に作用 する波圧と同程度にまで軽減されている様子が確認 できる，また，抵抗板が，屝体に直接作用寸る段波 の流れを遮ることにより，扉体下方に生じる波圧が 大きく低減されている様子がわかる．フラップゲー トの扉体の運動は, 関節部を持ったテンションロッ ドが直線状に伸びきった際に急静止し，その際に衝 撃的な波圧が作用する. 抵抗板を導入したことで, その流体抵抗により, 静止直前の扉体が持つ角速度 が抑制され, 角速度の低減率に応じて衝撃波圧も軽 減されることが，本数值解析を通して確認できた。

\section{5. おわりに}

本研究では，重合格子法を用いてフラップゲート の扉体および抵抗板の連成運動を取扱い, レベル セット法により構築した自由水面を用いて段波津波 の伝播, さらにフラップゲートへの段波の作用を再 現計算した. 衝撃的な波圧, ならびに角速度の変化 が非常に大きい扉体運動を伴う段波津波に対しても， 本解析手法が有効であることが確認され，抵抗板の 流体特性が明らかにされた。 また, 解析結果は, 水 理模型実験の結果, ならびに従来の実験式とも良好
に一致した。本研究を通して, 数值解析の有効性が 確認されたことにより，今後，フラップゲートの実 機設計の際には，実験ケースの簡略，あるいは省略 が可能となり, 経済的な設計を行うことができる.

謝辞 : 本研究の一部は, 科学研究費補助金・挑戦的 萌芽研究（代表：閒瀬 肇，研究課題名：津波リア ルタイム予測とフラップゲートによる津波被害防 止・軽減）による，ここに記して謝意を表する。

\section{参考文献}

1) 白井秀治, 藤田 孝, 木村雄一郎, 山口映二, 仲保京 一 : フラップ式可動ゲートの津波低減性能に関する模 型実験，海洋開発論文集，第22巻，pp.577-582，2006.

2) 木村雄一郎, 新里英幸, 仲保京一, 安田誠宏, 間瀬 肇：フラップゲート式可動防波堤の波浪応答特性に関 する実験的研究, 海岸工学論文集, 第56巻, pp.806810, 2009.

3) 木村雄一郎, 柳 浩敏, 森西晃嗣, 森 信人, 安田誠 宏, 間瀬 肇 : フラップゲート型構造物の流体連成解 析モデルの構築とその精度検証, 海洋開発論文集, 第 26巻, pp.237-242, 2010.

4) 木村雄一郎, 柳 浩敏, 森西晃嗣, 森 信人, 安田誠 宏, 間瀬 肇: 重合格子法を用いた流体-構造体連成モ デルによるフラップゲートの波浪応答解析, 土木学会 論文集B2（海岸工学）, 第66巻, pp.811-815, 2010.

5) 小幡正規, 中尾年雄, 里深信行, 森西晃嗣 : 重合格子 法による二次元バタフライ弁モデルの数值計算, 日本 機械学会論文集（B編），第59巻，562号，pp.220-226, 1993.

6) 和田好隆, 森西晃嗣, 松野謙一：レベルセット関数法 を用いた気泡の結合及び分離シミュレーション，第19 回数值流体力学シンポジウム, B5-5, 2005.

7) 谷本勝利, 鶴谷広一, 中野 晋 : 1983年日本海中部地 震における津波力と埋立護岸の被災原因の検討, 海岸 工学論文集, 第31巻, pp.257-261, 1984.

8) 池野正明, 森 信人, 田中寛好: 砕波段波津波による 波力と漂流物の挙動・衝突力に関する実験的研究, 海 岸工学論文集, 第48巻, pp.846-850, 2001. 